\title{
シンポジウム $\mathrm{I}-4$ \\ リウマチ性疾患患者 $\mathbf{B}$ 細胞が産生するリンフォカイン
}

澤田滋正・康浩一一戸村好太郎・三田村巧

Jpn. J. Clin. Immun., 11(5):471 474, 1988.

\section{I.はじめに}

全身性エリテマトーデス（SLE）や慢性関節リウマチ （RA）に代表される自己免疫病は，免疫異常特に抑制性 T細胞の欠陥によって, 多クローン B 細胞活性化が起こ り，自己抗体産生 B 細胞クローンのレパートリーが拡大 し，自己抗体が産生するものと考えられてきた。

一方，近年免疫担当細胞が合目的性を遂行するのに必 須である細胞間の調節因子が，次々に発見され同定され てきた。これらの調節生理的活性物翼が発見された当時 には，SLE P RA などの自己免疫病患者ではT細胞が これらの物質を大量に産生分泌しているものと考えられ ていたが，予想に反して，IL-1 や IL-2 の産生は低下 しており，またこれら堌殖分化因子に対する反応む低下 していることが分かり，多クローン性 B 細胞活性化のメ カニズムを説明するには，他の機序を考える必要に迫ら れていた.

われわれは SLE とRA を合併する患者末梢血から B 細胞株を樹立した.この細胞株 (TKS-1) の培養上清中 に，T細胞増殖を調節する可溶性因子を見出した.さら に，患者末梢血 B 細胞も spontaneously に同様な可溶性 因子を産生しているが，前述のB細胞株から産生される それとはいくらか生理的活性の違いが見出された．本報 告では, これらの可溶性因子の性状上生理的活性につい て述べた。

\section{II. 方法および材料}

B 細胞株培養上清: SLE とRA の合併した患者より 樹立した B 細胞株（TKS-1）を 10\% FCS 加 RPMI 1640 で $2 \times 10^{6} / \mathrm{ml}$ に調整し， 72 時間培養後の上清を用いた。

患 者 : RA 29 例(活動期 25 例, 非活動期 4 例), SLE

日本大学 第 1 内科
19 例 (活動期 3 例, 非活動期 16 例)について検討した。

B細胞分離 : 末梢血ヘパリン加採血 $60 \mathrm{~m} l$ にシリカ䀣 濁液 (KAC-II) を $6 \mathrm{~m} l$ 加え温浴中で 1 時間放置した 後, lymphocyte separating medium (LSM) に重層し 遠沈後，中間層を採取した。このリンパ球層を G-10 カ ラムを通過させ，さらにマクロファージ/単球を除去し， ナイロンカラムで $\mathrm{B}$ 細胞分画と $\mathrm{T}$ 細胞分画を得, 各々 1 $\times 10^{6} / \mathrm{ml}$ に細胞調節し, 無刺激で 72 時間培垦した。

ゲル濾過 : Sephacryl S-200を $1.3 \times 45 \mathrm{~cm}$ のカラム を用い, $\mathrm{pH} 7.4$ の $10 \mathrm{mM}$ PBSを $15 \mathrm{~m} l /$ 時の流速 で，培養上清をゲル滤過した。

可溶性因子の標識：TKS-1 細胞を L-[ $\left.{ }^{35} \mathrm{~S}\right]$ methionine を含む培養液中で培養することにより，TKS-1 細胞 から産生される蛋白を標識し，SDS-PAGE および fluorography で分析した. TKS-1 細胞 $2 \times 10^{5}$ 個を低濃度 $(3 \mu \mathrm{g} / \mathrm{ml}$ の cold methionine 含む modified iscove medium $/ \mathrm{m} l$ に浮遊させ, L-[ $\left.{ }^{35} \mathrm{~S}\right]$ methionine を添加 した. $24 \sim 48$ 時間培養後, 細胞を除去し, 培養上清中の蛋 白を SDS-バッファー pH 6.8 の $62.5 \mathrm{mM}$ Tris $/ \mathrm{HCl}$,

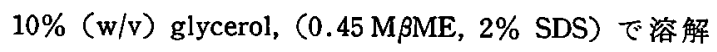
し， 2 分間煮沸処理し，電気泳動に供した.

SDS-PAGE およひ fluorography : SDS-PAGE は Studier ${ }^{1)}$ の slab-gel を用いて Laemmli ${ }^{21}$ の一般的方 法により行った. fluorography は Laskeyと Mills ${ }^{3}$ の方法によった・ゲルを乾燥後, 前処理したコダック X-Omat ARX 線フィルムに $-80^{\circ} \mathrm{C}$ で露光した. 基準 蛋白として Amersham $\left[{ }^{14} \mathrm{C}\right]$ の標識蛋白を用いた。

IL-1 活性の測定 : 4 8 週齢の $\mathrm{CH}_{3} / \mathrm{He}$ 雌マウスから 胸腺を採取し, Reisner ら゙)の方法によって PNA (EY 社）非凝集分画を得，DNA 合成能を測定した。胸腺細 胞 $1 \times 10^{8}$ 個を $0.8 \mathrm{mg} / \mathrm{ml}$ PNA 溶解液 $0.5 \mathrm{ml}$ で室温 10 分間反応させた.これに $5 \% \mathrm{FCS}$ 加 $\mathrm{MEM} / \mathrm{m} l$ を加え, $20 \%$ FCS 加 MEM の上に静かに重層させ, 室温で 30 


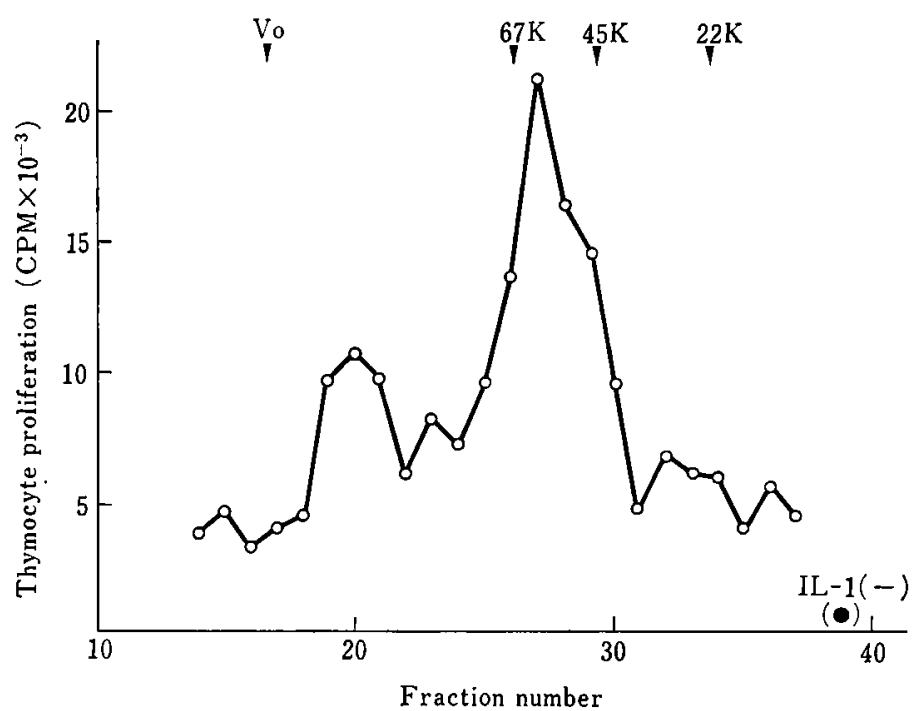

図 1 TKS-1 細胞株培美上清の Sephacryl S-200 カラムによる BGEF-1 の分離

分間静置した。 上層部 PNA 非凝集胸腺細胞を採取し, MEM で 2 回洗浄後, d-galactose 溶液 $2 \mathrm{ml}$ で混和し, 室温で 10 分間反応させ PNA を不活化した．この細胞 浮遊液 $100 \mu l$ ずつをマイクロプレートに分注, 72 時間 培養し，その DNA 合成能を測定した. IL-1 による増 殖增強能は，培養上清ゲル滤過後の各分画 $25 \%(\mathrm{v} / \mathrm{v})$ をとト単球由来 IL-1 (Genzyme : GUP 1-1) とともに 72 時間培羡し, DNA 合成能を測定した。

IL-2 活性の測定 : マウスの IL-2 依存性細胞株 CTLL （福井医科大学, 星野教授上り供与）を用い, $1 \times 10^{5} / \mathrm{ml}$ とした CTLLを $100 \mu l$ マイクロプレートに分注, 24 時間後の DNA 合成を測定した．また，IL-2 との共存 下での CTLL 増殖に及ぼす影響を検討するため, recombinant human IL-2（武田製薬，大阪）を用いた。

\section{III. 結 果}

TKS-1 細胞培美上清は, 末梢血 T細胞の低濃度 Con Aに対する反応を抑制し，高濃度 Con A に対する反応 を増強した．この培養上清を Sephacryl S-200 ゲゲル 滤過し，各分画の IL-1 活性, IL-1 に対する影響を検討 した.いずれの分画も IL-1 活性は認められなかった が, 一定量のヒト精製 IL-1 を涯加したところ，分子量 約 $60 \mathrm{kd}$ にIL-1 による増殖を著明に増強する分画が得 られた（図 1). しかし，この分画はIL-2 依存性細胞株 CTLL/2 を用いた検討で, IL-2 活性もなく、また IL-2 による増殖を増強する活性も認められなかった。

この IL-1 による増殖増強因子が TKS-1 細胞から 産生される掻白であるか不か, 可溶性因子の L-[ $\left.{ }^{35} \mathrm{~S}\right]$ methionine による内部標識を行った。培養上清をまず Sephacryl S-200 カラムによるゲル滤過後, 各分画を SDS-PAGE および fluorography で分析したところ, フ ラクション $27(60 \mathrm{kd})$ に ${ }^{35} \mathrm{~S}-$ methionine 標識蛋白が認 められ，この蛋白は還元状態の SDS-PAGE で低分子領 域への分離が認められず, S-S 結合をもたない蛋白であ ることが示唆された．この $60 \mathrm{kd} の$ 蛋白に IL-1 による 増殖増強活性が認められた。この蛋白を B cell derived growth enhancing factor-1 (BGEF-1) とした.

この BGEF-1 を実際に患者末梢血 B 細胞が産生して いるか否かを検討した，SLE と RA 患者のB細胞培養 上清は，IL-1 に上る増殖増強は 135士94\% であるが， 正常人のそれは $6 \pm 21 \%$ であった $(P<0.01)$ (図 2). IL-1 活性は認められなかった。また, 患者 $\mathrm{T}$ 細胞培養上 清には増殖増強はほとんど認められなかった. PNA 胸 腺細胞増殖は IL-1, IL-2 の両者に依存しているため, その特異性について検討した. その結果, IL-2 依存性 細胞株である CTLL/2 の增殖を增強するが，線維芽細 胞の IL-1 による増殖は増強しなかった。

さらに，患者末梢血B細胞培養上清を Sephacryl S200 カラムによるゲル滤過では, 分子量的 $20 \mathrm{kd}$ に IL-2 による細胞増殖増強活性を認めた．この因子を B cell derived growth factor-2 (BGEF-2) とした. BGEF-2 は DNA 合成のみならず細胞実数も増強した.

さらに，IL-2 受容体に及ぼす影響について検討した。 IL-2 受容体の測定は YT 細胞 (京都大学, 淀井博士よ り供与）を用い, BGEF-2 を添加し，24時間培荃した 後, 抗 Tac 抗体によって Tac 抗原の発現を FACS 


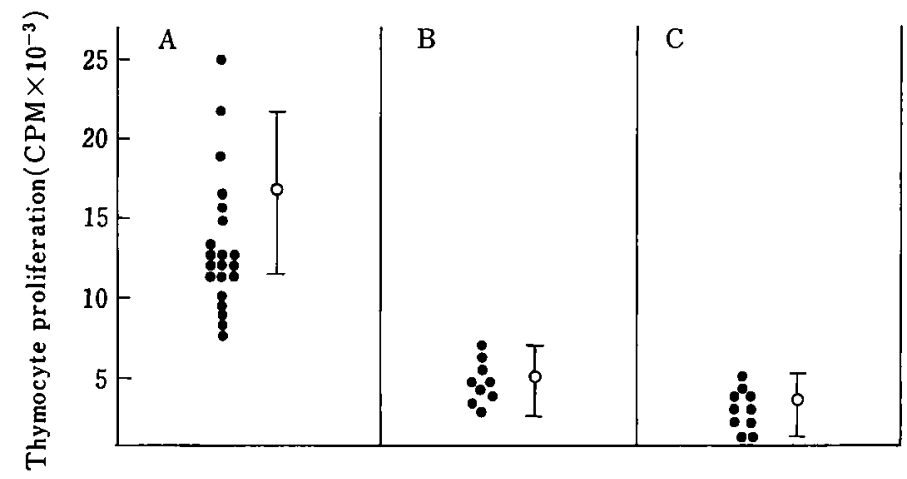

図 2 患者末梢血リンパ球培羕上清の IL-1 によるマウス胸腺細胞增殖 に及ぼす影響
A : RA 患者末梢血 B 細胞培養上清
$B$ ：正常人末梢血 B 細胞培垗上清
$\mathrm{C}: \mathrm{RA}$ 患者末梢血 $\mathrm{T}$ 細胞培羕上清
$A$ vs $B(p<0.01), A$ vs $C(p<0.01)$

analyzer で検討した.その結果, BGEF-2 は IL-2 受 容体の誘遒発現作用を有さなかった。また，抗マウス IL-2 受容体抗体を CTLL/2 細胞に処理すると, BGEF2 による細胞増強活性は認められなかった。

さらに，既存のサイトカイン，IFN, IL-4, IL-5, IL-6, TNF を,それぞれが以上の上うな IL-2 に上る細胞増殖 活性を有するか否かを検討したが，どれもその活性を認 めなかった. また，正常人 B細胞を刺激しても BGEF1，2 は見出されなかった。

\section{IV. 考案}

SLE 患者や RA 患者では, 非特異的抑制性 $\mathrm{T}$ 細胞機 能低下と多クローン性 B 細胞活性化が認められ，リウマ 千性疾患患者の主な免疫異常と考えられている，特に， 多クローン性 B 細胞活性化の分子論的解析はほとんどな されていないのが現状である。

最近，明らかにされた $\mathrm{T}$ 細胞由来の $\mathrm{B}$ 細胞増殖分化因 子, IL-4, IL-6 が, SLE 患者や RA 患者において産生 六進がみられるか否か興味あるが，その報告は現在まで ない. 特に SLE 患者では, IL-5 や IL-6 が多クローン 性B細胞活性化に重要な役割を果たしているといら証拠 は今のところない. EB ウイルスによってトランスフォ ームされた B 細胞株は，自己増殖を刺激する可溶性因子 を産生している5)，すなわち, autocrine システムによ り增殖が起こっている可能性が示された.リウマチ性疾 患患者で認められる多クローン性 B 細胞活性化は， B 細 胞自身から産生される因子による可能性がある，最近， B細胞加産生される可溶性因子として, Scala ら ${ }^{6)}$ $\mathrm{EB}$ ウイルスでトランスフォームしたB細胞株から，
IL-1 と IL-1 拮抗物質が産生されていることを報告して いる.この IL-1 活性は抑制因子共存のため, 培養上清 では認められず，ゲル滤過によって初めて明らかとなっ た. Matsushima らクにより，正常者のB細胞から LPS 刺激によって IL-1 が産生されることが報告されてい 万.

われわれの樹立した TKS-1 細胞培養上清をゲル滤過 したところ，IL-1 活性を認めなかった. BGEF-1 は ${ }^{35} \mathrm{~S}-$ methionine の内部蛋白標識によって, 還元下での SDSPAGE でも解離せず, IL-I あるいは IL-2 の重合体と は考え難かった. Teshigawara ら HTLV-1 T 細胞株由来の可溶性因子である ADF は, $15 \sim 20 \mathrm{kd}$ と $35 \sim 40 \mathrm{kd}$ の 2つの分子があり, IL-2 受容 体誘導活性を有し，IL-1, IL-2 の costimulator 活性を 有する. BGEF-1 は IL-2 による細胞増殖を増強せず， IL-2 受容体の発現率にも影響を与えなかった. 以上の ことより BGEF-1 は ADF とは違った分子であろうと 思われる.

われわれは患者末梢血から樹立された B 細胞株がユニ 一クな IL-1 活性を増強する可溶性因子を見出したので， 実際に患者末梢血から精製した B 細胞培養上清中に同様 な因子が産生されるか否かを検討したところ，興味ある ことに IL-2 に対する増強因子が得られた． IL-2 の活性 を増強する cofactor としては，TCGPF やレンチナン がある.しかし, 生体内から IL-2 活性を増強する生理 的活性物質の報告はない,この可溶性因子が正常者のB 細胞を刺激しても見出されない事実は，この因子はリウ マチ性疾患の病因に樑くかかわっている可能性がある. 


\section{V. おわりに}

リウマチ性疾患患者 $\mathrm{B}$ 細胞は，正常人 B 細胞を刺激し

ても産生しないユニークな細胞堌殖増強可溶性因子を産
生していることを見出した．この因子は，多クローン性 B 細胞活性化に重要な役割をにな5生理的活性物犋であ る可能性がある.

文献

1) Studier, F.W. : Analysis of bacteriophage T 7 early RNAs and proteins on slab gels. J. Mol. Biol., 79 : 237, 1973.

2) Laemmli, U.K. : Cleavage of structural proteins during the assenbly of the head of bacteriophage T 4. Nature, $227: 680,1970$.

3) Laskey, R.A., Mills, A.D. : Quantitative film detection of ${ }^{3} \mathrm{H}$ and ${ }^{14} \mathrm{C}$ in polyacrylamide gels by fluorography. Eur. J. Biochem., $56: 335$, 1975.

4) Reisner, Y., Linker-Israeli, M., Sharon, N. : Separation of mouse thymocytes into two subpopulation by the use of peanut agglutinin. Cell. Immunol., 25, 129, 1976.

5) Buck, J., Hämmerling, V., Hoffmann, M.K. et al. : Purification and biochemical characterization of a human autocrine growth factor pro-

duced by Epstein-Barr virus transformed B cells. J. Immunol., 138 : 2923, 1987.

6) Scala, G., Kuang, Y.D., Hall, R.E. et al. : Accessory cell function of human B cells. I production of both interleukin 1-like activity and an interleukin 1 inhibitory factor by an EBVtransformed human B cell line. J. Exp. Med., $159: 1637,1984$.

7) Matsushima, K., Procopio, A., Abe, H. et al. : Production of interleukin 1 activity by normal human peripheral blood B lymphocytes. J. Immunol., $135:$ 1132, 1985.

8) Teshigawara, K., Maeda, M., Nishino, K. et al. : Adult $\mathrm{T}$ leukemia cells produce. a lymphokine that augment interleukin 2 receptor expression. J. Mol. Cell. Immunol., 2, 17, 1985. 